\title{
PENGARUH BUDAYA ORGANISASI DAN KOMPENSASI TERHADAP KEPUASAN KERJA PEGAWAI PADA DINAS PEMBERDAYAAN MASYARAKAT GAMPONG (DPMG) KABUPATEN PIDIE
}

\author{
Syamsul Akmal ${ }^{(1)}$, Raisnaiyah ${ }^{(2)}$ \\ Program Studi Manajemen Fakultas Ekonomi Universitas Jabal Ghafur \\ E-mailsyamsul_akmal24@yahoo.com
}

\begin{abstract}
ABSTRAK
Penelitian ini bertujuan untuk menguji pengaruh budaya organisasi dan kompensasi terhadap kepuasan kerja pegawai pada Dinas Pemberdayaan Masyarakat Gampong (DPMG) Kabupaten Pidie. Jumlah sampel diambil sebanyak 41 pegawai dengan metode total samling. Adapaun data di analsisi dengan menggunaan SPSS versi 22. Sebelum dilakukan Analisi Regresi Lineier Berganda terlebih dahulu dilakukan uji validitas dan reliabiltas data. Selanjutnya uji Asumsi Klasik yang meliputi uji normalitas, heteroskedastisitas dan multikolonearitas. Hasil analisis Regresi Linier Berganda diperoleh persamaan sebagai berikut: $Y=\mathbf{2 , 0 3 4}+\mathbf{0 . 3 6 1} X^{1}+\mathbf{0 . 5 1 9} X^{2}$.

Dari hasil perhitungan pada Tabel 4.11 di atas, diperoleh $F_{\text {hitung }}$ 33,067 dengan tingkat probabilitas 0,00 , sedangkan $F_{\text {tabel }}$ sebesar 3,245. Karena probabilitas jauh lebih kecil dari $0,05 . F_{\text {hitung }}$ lebih besar dari $F_{\text {tabel }}$ maka dapat dikatakan bahwa benar variabel kepuasan kerja dipengaruhi secara simultan (bersama-sama) dan signifikan oleh budaya organisasi dan kompensasi pada Dinas Pemberdayaan Masyarakat Gampong Kabupaten Pidie. Hasil penelitian terhadap pengaruh budaya organisasi diperoleh nilai $t_{\text {hitung }} 2,669$ sedangkan untuk nilai $t_{\text {tabel }} 2,02$. Karena nilai $\mathrm{t}_{\text {hitung }}$ lebih besar dari $\mathrm{t}_{\text {tabel }}$ dengan tingkat signifikan sebesar 0.011 lebih kecil dari 0,05 dapat disimpulkan bahwa budaya organisasi memiliki pengaruh secara parsial dan signifikan terhadap kepuasan kerja pada Dinas Pemberdayaan Masyarakat Gampong. Selanjutnya hasil penelitian terhadap pengaruh kompensasi diperoleh nilai $t_{\text {hitung }} 3,375$ sedangkan untuk nilai $t_{\text {tabel }} 2,02$. Karena nilai $t_{\text {hitung }}$ lebih besar dari $t_{\text {tabel }}$ dengan probabilitasnya sebesar 0.002 lebih kecil dari 0,05 dapat diartikan bahwa kompensasi memiliki pengaruh secara parsial dan signifikan terhadap kepuasan kerja pada Dinas Pemberdayaan Masyarakat Gampong.
\end{abstract}

Kata Kunci : Budaya Organisasi, Kompensasi dan Kepuasan Kerja.

\section{PENDAHULUAN}

\subsection{Latar Belakang Masalah}

Budaya organisasi berperan

penting dalam meningkatkan

kepuasan kerja yang efektif dan

efisien pada Kantor Dinas

Pemberdayaan Masyarakat Gampong (DPMG). Budaya merupakan tolak ukur untuk mencapai kesuksesan organisasi selain itu juga membangun

komitmen mewujudkan visi,, memenangkan persaingan dan membangun kekuatan organisasi. Bagi individu, budaya mendorong pegawai memiliki rasa kepercayaan yang tinggi terhadap organisasi serta menjadi lebih produktif. Budaya organisasi merupakan norma - norma 
dan nilai - nilai yang mengarahkan perilaku anggota organisasi. Setiap anggota organisasi akan berperilaku sesuai dengan budaya yang berlaku agar di terima oleh lingkungannya. Budaya organisasi juga sebagai pemersatu pegawai, peredam konflik dan motivator pegawai untuk melaksanakan tugas dengan baik, sehingga berpengaruh positif terhadap kepuasan pegawai. Suatu organisasi yang memiliki budaya yang kuat akan menghasilkan kepuasan yang baik.

Kompensasi merupakan segala sesuatu yang di terima oleh pegawai yang di berikan oleh organisasi sebagai balas jasa atau sumbangan tenaga dan pikiran demi kemajuan organisasi. Kompensasi di harapkan mampu merangsang atau memotivasi semangat kerja pegawai sehingga pegawai dapat memberikan kinerja terbaik untuk organisasi yang akan berdampak pada kepuasan kerja dan kualitas pelayanan pegawai di berbagai instansi swasta atau BUMN. Seperti halnya juga terus meningkatkan kemampuan organisasi untuk mencapai kinerja terbaik. Salah satu cara yang di lakukan Dinas Pemberdayaan Masyarakat Gampong (DPMG) dalam meningkatkan kinerja adalah memberikan kompensasi sebagai salah satu faktor yang di harapkan mampu memotivasi semua pegawai untuk menghasilkan kualitas pelayanan yang di harapkan.

Kepuasan kerja adalah hasil dari persepsi pegawai mengenai seberapa baik pekerjaan mereka memberikan hal yang di nilai penting. Sikap ini di cerminkan oleh moral kerja, kedisiplinan dan prestasi kerja. Kepuasan kerja di nikmati dalam pekerjaan, luar pekerjaan, dan kombinasi dalam dan luar pekerjaan. Kepuasan kerja pegawai di pengaruhi oleh lingkungan kerja pegawai, baik lingkungan di antara para pegawai maupun hubungan dengan manajemen di atasnya. Kepuasan kerja pegawai harus di perhatikan secara serius oleh setiap organisasi. Ketidakpuasan menjadi titik awal pada munculnya masalah - masalah dalam organisasi seperti kemangkiran, konflik atasan dengan pekerja, tingkat absensi yang tinggi, adanya pemogokan dan perputaran pegawai. Dari sisi pekerja, ketidakpuasan dapat menyebabkan menurunnya motivasi, menurunnya moral kerja, dan menurunnya tampilan kerja baik secara kualitatif maupun secara kuantitatif. Kepuasan kerja yang tinggi akan memberikan dampak positif terhadap pegawai seperti timbulnya loyalitas dan di siplin terhadap pekerjaan serta akan meningkatkan kinerja pegawai tersebut.

Rasa aman terhadap keselamatan akan suasana kerja yang mampu mendorong pegawai untuk lebih berdedikasi tinggi dalam menyelesaikan tugas yang di beri oleh pimpinan, baik suasana aman sebelum bekerja maupun setelah bekerja. Kondisi kerja yang seperti ini, serta di dukung rekan kerja yang dapat di ajak kerjasama juga merupakan faktor yang di harapkan pengawai untuk dapat bekerja maksimal agar dapat mendapatkan kepuasaan dalam bekerja.

Melihat pentingnya peranan Kantor Dinas Pemberdayaan Masyarakat Gampong (DPMG) dalam perangkat Pemerintah Kabupaten Pidie, sudah layaknya lembaga ini berusaha meningkatkan kualitas sumber daya manusia yaitu pengawai dalam menjalakan tugas yang di bebankannya. Terpenuhinya kepuasaan kerja pengawai kantor 
Dinas Pemberdayaan Masyarakat Gampong (DPMG) bisa memberikan pandangan yang baik bagi instansi yang lain dan dapat menjadi contoh dalam meningkatkan kualitas pengawai/bawahanya.

Setiap organisasi memiliki masalah yang berbeda-beda, seperti budaya lama yang tidak sesuai dengan nilainilai budaya organisasi baru dan kompensasi jika di berikan secara benar maka pegawai akan lebih terpusatkan dan termotivasi untuk mencapai sasaran-sasaran organisasi. Apabila pegawai memandang kompensasi yang diterimanya tidak memadai maka akan berakibat pada turunya prestasi, motivasi dan kepuasan kerja secara drastis..

Berdasarkan permasalahan yang telah diuraikan di atas, Oleh karna itu, penulis ingin mengkaji permasalahan yang berhubungan dengan dimensi budaya, kompensasi dalam mempengaruhi kepuasaan kerja, yang berjudul“" Pengaruh Budaya Organisasi dan Kompensasi Terhadap Kepuasaan Kerja Pengawai Pada Dinas Pemberdayaan Masyarakat Gampong (DPMG)".

\subsection{Rumusan Masalah}

Berdasarkan latar belakang penelitian di atas, maka masalah dapat di rumuskan :

1. Bagaimana pengaruh budaya organisasi terhadap kepuasaan kerja pada Dinas Pemberdayaan Masyarakat Gampong (DPMG)

2. Bagaimana pengaruh kompensasi terhadap kepuasaan kerja pada Dinas Pemberdayaan Masyarakat Gampong (DPMG)

3. Bagaimana pengaruh budaya organisasi dan kompensasi terhadap kepuasan kerja

\author{
secara simultan pada Dinas \\ Pemberdayaan Masyarakat \\ Gampong (DPMG)
}

\subsection{Tujuan Penelitian}

Berdasarkan perumusan masalah di atas, maka yang menjadi tujuan penelitian adalah :

1. Untuk mengetahui pengaruh budaya organisasi terhadap kepuasaan kerja pada Dinas Pemberdayaan Masyarakat Gampong (DPMG)

2. Untuk mengetahui pengaruh kompensasi terhadap kepuasaan kerja pada Dinas Pemberdayaan Masyarakat Gampong (DPMG)

3. Untuk mengetahui pengaruh budaya organisasi dan kompensasi terhadap kepuasan kerja secara simultan pada Dinas Pemberdayaan Masyarakat Gampong (DPMG)

\subsection{Manfaat Penelitian}

Penelitian ini di harapkan memberikan kegunaan sebagai berikut:

1. Sebagai bahan masukan ilmiah bagi Pimpinan Dinas Pemberdayaan Masyarakat Gampong (DPMG) Kabupaten Pidie dalam mengembangan kualitas sumber daya manusia.

2. Bagi penulis atau peneliti, yakni:

a. Sebagai sarana menambah pengetahuan teoritis tentang budaya organisasi dan kompensasi terhadap kepuasan kerja pegawai.

b. Sebagai sarana pengembangan ilmu pengetahuan yang secara teoritis telah di terima di bangku kuliah.

3. Bagi pembaca, yakni dapat di jadikan sebagai acuan atau bahan 
perbandingan untuk melakukan penelitian yang relevan selanjutnya.

\section{STUDI KEPUSTAKAAN}

\subsection{Budaya Organisasi}

\subsubsection{Pengertian}

Organisasi

Menurut Luthans (2011:137) mengemukakan bahwa budaya organisasi adalah pola pemikiran dasar yang diajarkan kepada personel baru sebagai cara untuk merasakan, berfikir dan bertindak secara benar dari hari-kehari.

Robbins dan Judge (2010:256) berpendapat bahwa: "Budaya organisasi mengacu ke sistem makna bersama yang dianut oleh anggota-anggota yang membedakan organisasi itu dari organisasi-organisasi lain. Sistem makna bersama ini, bila diamati dengan lebih seksama, merupakan seperangkat karakteristik utama yang dihargai oleh organisasi itu.

Sutrisno

(2014:2),

mendefinisikan Budaya organisasi sebagai perangkat sistem nilai-nilai (values), keyakinan-keyakinan (beliefs), asumsi-asumsi (asumptions), atau norma-norma yang telah lama berlaku, disepakati dan diikuti oleh para anggota suatu organisasi sebagai pedoman perilaku dan pemecahan masalah-masalah organisasinya.

Mangkunegara (2013: 13), berpendapat bahwa "Budaya organisasi adalah seperangkat asumsi atau sistem keyakinan, nilai-nilai, norma-norma yang dikembangkan dalam organisasi yang dijadikan pedoman tingkah laku bagi anggotaanggotanya untuk mengatasi masalah adaptasi eksternal dan internal."
Berdasarkan beberapa definisi diatas menunjukan bahwa budaya organisasi merupakan falsafah, ideologi, nilainilai, anggapan, keyakinan, harapan, sikap dan norma-norma yang dimiliki secara bersama serta mengikat yang merupakan bentuk bagaimana orangorang dalam organisasi berperilaku dan melakukan sesuatu hal yang bisa dilakukan dan dimana membedakan organisasi itu dari organisasiorganisasi lain. Budaya organisasi akan meningkatkan motivasi kerja pegawai dengan memberi mereka perasaan memiliki, loyalitas, kepercayaan, nilai-nilai dan mendorong mereka berpikir positif tentang mereka dan organisasi. Dengan demikian, organisasi itu memaksimalkan potensi pegawai dan memenangkan kompetisi. Budaya organisasi juga akhirnya akan berfungsi sebagai motivator bagi pegawai dalam melaksanakan pekerjaannya.

\subsubsection{Fungsi Budaya Organisasi}

Fungsi budaya organisasi menurut Sembering, (2012:64-66) Yaitu:

1) Budaya mempunyai suatu peran menetapkan tanpa batas. Artinya, budaya menciptakan pembedaan yang jelas antara satu organisasi dengan yang lainnya.

2) Budaya membawa suatu rasa indentitas bagi anggotaanggota organisasi.

3) Budaya mempermudah timbulnya komitmen pada sesuatu yang lebih luas dari pada kepentingan dari individual seseorang.

4) Budaya meningkatkan kemantapan sistem sosial, budaya merupakan perekat 
sosial yang membantu mempersatukan organisasi itu dengan memberikan standarstandar yang tepat mengenai apayang harus dikatakan dan dilakukan oleh para pegawai.

5) Budaya berfungsi sebagai mekanisme pembuat makna dan kendali yang memadu dan membentuk sikap serta perilaku para pegawai.

Fungsi budaya organisasi menurut Robbins (2010: 248) adalah sebagai berikut:

1) Budaya menciptakan pembedaan yang jelas antara satu organisasi dan yang lain.

2) Budaya membawa suatu rasa identitas bagi anggotaanggota organisasi.

3) Budaya mempermudah timbulnya komitmen pada sesuatu yang lebih luasdaripadakepentingan diri individual seseorang.

4) Budaya merupakan perekat sosial yang membantu mempersatukan organisasi itudengan memberikan standar- standar yang tepat untuk di lakukan oleh pegawai.

5) Budaya sebagai mekanisme pembuat makna dan kendali yang memadu dan membentuk sikap serta perilaku pegawai.

Menurut Kinicki dan Fugate (2013 : 35) fungsi budaya organisasi adalah sebagai berikut :

1) Memberikan anggota identitas organisasi

2) Memfasilitasi komitmen bersama
3) Meningkatkan stabilitas sistem sosial

4) Membentuk perilaku dengan membantu anggota memahami lingkungan mereka

\subsubsection{Indikator Budaya Organisasi}

Menurut Robbins (2010:256-257), indikator budaya organisasi adalah sebagai berikut:

1. Inovasi dan keberanian mengambil resiko

Sejauh mana pegawai didorong untuk bersikap inovatif dan berani mengambil resiko.

2. Perhatian pada hal-hal rinci

Sejauah mana pegawai diharapkan menjalakan presisi, analisis dan perhatian pada halhal detail.

3. Orientasi hasil kerja

Sejauh mana manajemen berfokus lebih pada hasil ketimbang pada tenik dan proses yang digunakan untuk mencapai hasil tersebut.

4. Orientasi pada anggota organisasi

Sejauh mana keputusankeputusan manajemen mempertimbangkan efek dari hasil tersebut atas manusia yang ada dalam organisasi ketimbang pada individu-individu.

5. Orientasi tim

Sejauh mana kegiatankegiatan kerja organisasi pada tim ketimbang individuindividu.

6. Keagresifan

Sejauh mana orang bersikap agresif kompentitif ketimbang santai dan hanya diam saja. 
Indikator Budaya Organisasi diuraikan sebagai berikut menurut Edison (2016:131) :

1. Kesadaran diri. Anggota organisasi kesadarannya bekerja untuk mendapatkan kepuasan dari pekerjaan mereka, mengembangkan diri, menanati aturan, serta menawarkan produk-produk berkualitas dan layanan tinggi.

a) Anggota mendapatkan kepuasan atas pekerjaannya.

b) Anggota berusaha untuk menggembangkan diri dan kemampuannya.
c) Anggota menanti peraturan-peraturan yang ada.

2. Keagresifan. Anggota organisasi menetapkan tujuan yang menantang tapi realitis. Mereka menetapkan rencana kerja dan strategi untuk mencapai tujuan serta mengerjarnya dengan antusiasi.

a) Anggota penuh inisiatif dan tidak selalu tergantung pada petunjuk pimpinan.

b) Anggota menetapkan rencana dan berusaha untuk menyelesaikan dengan baik.

3. Kepribadian. Anggota bersikap saling menghormati, ramah, terbuka dan peka terhadap kepuasan kelompok serta sangat memperhatikan aspek-aspek kepuasan pelanggan, baik pelanggan internal maupun eksternal.
a) Setiap anggota saling menghormati dan memberikan salam pada saat perjumpaan.

b) Anggota kelompok saling membantu.

c) Masing-masing anggota saling menghargai perbedaan pendapat.

4. Performa. Anggota organisasi memiliki nilai kreatifitas, memenuhi kuantitas, mutu, dan efisien.
a) Anggota selalu mengutamakan kualitas dalam menyelesaikan pekerjaannya.
b) Anggota selalu berinovasi untuk menemukan hal-hal baru dan berguna.
c) Setiap anggota selalu berusaha untuk bekerja dengan efektif dan efisien.

5. Orientasi tim. Anggota organisasi melakukan kerjasama yang baik serta melakukan komunikasi dan koordinasi yang efektif dengan keterlibatan aktif para anggota, yang pada gilirannya mendapatkan hasil kepuasan tinggi serta komitmen bersama. dilakukan dengan diskusi dan disinergikan.
a) Setiap tugas-tugas tim
b) Setiap ada permasalahan dalam tim kerja selalu diselesaikandengan baik.
Menurut Desinon (2017:194) indikator budaya organisasi adalah sebagai berikut :

1. Involvement, adalah dimensi budaya organisasi yang nenunjukkan tingkat partisipasi karyawan (anggota organisasi) dalam proses pengambilan keputusan .

2. Consistency, menunjukan tingkat kesepakatan anggota organisasi terhadap asumsi 
dasar dan nilai-nilai organisasi.

3. Adaptability, adalah kemampuan organisasi dalam merespon perubahanperubahan lingkungan eksternal dengan melakukan perubahan internal organisasi.

4. Mission Dimension, adalah dimensi budaya yang menunjukan tujuan inti organisasi yang menjadikan anggota organisasi teguh dan fokus terhadap apa yang dianggap penting oleh organisasi.

\subsection{Kompensasi}

\subsubsection{Pengertian Kompensasi}

Masalah kompensasi sensitif karna menjadi pendorong seseorang untuk bekerja juga berpengaruh terhadap moral dan disiplin tenaga kerja.Oleh karna itu, setiap organisasi manapun seharusnya dapat memberikan kompensasi yang seimbang dengan beban kerja yang dipikul tenaga kerja. Berikut ini akan dikemukakan beberapa definisi dari kompensasi.

Menurut Hasibuan (2012:118) mendefinisasikan, "Kompensasi adalah semua pendapatan yang berbentuk uang, barang langsung atau tidak langsung yang diterima pegawai sebagai imbalan atas jasa yang diberikan oleh organisasi".

Sedangkan, menurut Rivai (2011:357) menjelaskan bahwa, "Kompensasi merupakan sesuatu yang pegawai dapatkan sebagai pengganti kontribusi jasa mereka pada pegawai".

Menurut Pangabean (2012:176) kompensasi adalah setiap bentuk penghargaan yang diberikan pegawai sebagai balas jasa atas kontribusi yang mereka berikan kepada organisasi.
Menurut Dessler dalam Yani (2012:175) kompensasi adalah setiap bentuk pembayaran atau imbalan yang diberikan kepada pegawai dan timbul dari pekerjaannya pegawai itu. Sistem imbalan bisa mencakup gaji, penghasilan, uang pensiun, uang liburan, promosi ke posisi yang lebih tinggi.Juga berupa asuransi keselamatan kerja, tranfer secara horizontal untuk mendapat posisi yang lebih menantang atau keposisi utama untuk pertumbuhan dan pengembangan berikutnya, serta berbagai macam bentuk pelayanan.

Jadi berdasarkan beberapa pengertian diatas secara umum dapat dikatakan bahwa kompensasi itu merupakan balas jasa yang diterima oleh pegawai sehubungan dengan pengorbanan yang telah diberikan kepada organisasi.Pemberian kompensasi ini bisa diberikan langsung berupa uang maupun tidak langsung berupa uang dari perusahaan ke pegawainya.

\subsubsection{Tujuan Pemberian Kompensasi}

Menurut Hasibuan (2012:121-122) tujuan pemberian kompensasi adalah sebagai berikut:

a. Ikatan Kerja Sama; Dengan pemberian kompensasi terjalin ikatan kerja sama formal antara majikan dengan pegawai. Pegawai harus mengerjakan tugas-tugasnya dengan baik, sedangkan pengusaha/majikan wajib membayar kompensasi sesuai dengan perjanjian yang disepakati.

b. Kepuasan Kerja; Dengan balas jasa, pegawai akan dapat memenuhi kebutuhankebutuhan fisik, status sosial dan egoistiknya sehingga 
memperoleh kepuasan kerja dari jabatannya.

c. Pengadaan Efektif; Jika program kompensasi ditetapkan cukup besar, pengadaan pegawai yang qualified untuk organisasi akan lebih mudah.

d. Motivasi; Jika balas jasa yang diberikan cukup besar, manajer akan mudah memotivasi bawahannya.

e. Stabilitas pegawai; Dengan program kompensasi atas prinsip adil dan layak serta eksternal konsistensi yang kompetitif maka stabilitas pegawai lebih terjamin karena turn-over relatif kecil.

f. Disiplin; Pemberian balas jasa yang cukup besar maka disiplin pegawai semakin baik. Mereka akan menyadari dan mentaati peraturan-peraturan yang berlaku.

g. Pengaruh Serikat Buruh; Dengan program kompensasi yang baik pengaruh serikat buruh dapat di hindarkan dan pegawai akan berkonsentrasi pada pekerjaannya.

h. Pengaruh Pemerintah; Jika program kompensasi sesuai dengan undang undang perburuhan yang berlaku (seperti batas upah minimum), maka intervensi pemerintah dapat dihindarkan.

Secara sederhana dapat disimpulkan bahwa pemberian kompensasi hendaknya memberikan kepuasan kepada pegawai, sehingga dapat diperoleh pegawai yang handal dan berkualitas serta dapat mempertahankan pegawai yang ada saat ini.

Menurut Rivai (2011:743) tujuan kompensasi yaitu :
Memperoleh SDM yang berkualitas .Kompensasi yang cukup tinggi sangat dibutuhkan untuk memberi daya tarik kepada para pelamar.Tingkat para pengusaha berkompetisi untuk mendapatkan pegawai yang diharapkan:

a. Mempertahankan pegawai yang ada. Para pegawai dapat keluar jikabesaran kompensasi tidak kompetitif dan akibatnya akan menimbulkan perputaran pegawai yang semakin tinggi.

b. Menjamin keadilan.

Manajemen kompensasi selalu berupaya agar keadilan internal dan eksternal dapat terwujud. Keadilan internal mensyaratkan bahwa pembayaran dikaitkan dengan nilai relatif sebuah pekerjaan sehingga pekerjaan yang sama dibayar dengan besaran yang sama. Keadilan eksternal berarti pembayaran terhadap pekerja merupakan yang dapat di bandingkan dengan organisasi lain di pasar kerja.

c. Penghargaan terhadap perilaku yang di inginkan. Pembayaran hendaknya memperkuat perilaku yang di inginkan dan bertindak sebagai insentif untuk perbaikan perilaku dimasa depan, rencana kompensasiefektif, menghargai kinerja, ketaatan, pengalaman, tanggung jawab, dan perilaku-perilaku lainnya.

d. Mengendalikan biaya. Sistem kompensasi yang rasional membantu organisasi memperoleh dan mempertahankan para pegawai dengan biaya yang beralasan. Tanpa manajemen 
kompensasi efektif, bisa jadi pekerja dibayar dibawah atau diatas standar.

e. Mengikuti aturan hukum. Sistem gaji dan upah yang sehat mempertimbangkan faktor-faktor legal yang dikeluarkan pemerintah dan menjamin pemenuhan kebutuhan pegawai.

f. Memfasilitasi pengertian. Sistem manajemen kompensasi hendaknya dengan mudah dipahami oleh spesialis SDM, manajer operasi, dan para pegawai.

g. Meningkatkan efisiensi administrasi. Program pengupahan dan penggajian hendaknya dirancang untuk dapat dikelola dengan efisien, membuat sistem informasi SDM optimal, meskipun tujuan ini hendaknya sebagai pertimbangan sekunder dibandingkan dengan tujuantujuan lain.

Dari uraian di atas dapat disimpulkan bahwa pemberian kompensasi hendaknyamemberikan kepuasan bagi pegawai, sehingga dapat diperoleh pegawai yang kompeten, handal, dan berkualitas serta dapat mempertahakan dan selalu meningkatkan kinerjanya.

Menurut Kadarisman (2012 : 78) tujuan pemberian kompensasi adalah :

1. Pemenuhan kebutuhan ekonomi, pegawai menerima kompensasi berupa upah, gaji atau bentuk lainnya adalah untuk memenuhi kebutuhan hidupnya sehari-hari atau dengan kata lain, kebutuhan ekonominya. Dengan adanya kepastian menerima upah atau gaji, tersebut secara periodik, berarti adanya jaminan "economi security" bagi dirinya dan keluarga yang menjadi tanggung jawabnya.

2. Meningkatkan produktivitas kerja, pemberian kompensasi yang makin baik akan mendorong pegawai bekerja produktif.

3. Memajukan organisasi, semakin berani suatu organisasi memberikan kompensasi yang tinggi, semakin menunjukan betapa makin suksesnya organisasi, sebab pemberian kompensasi yang tinggi mungkin apabila pendapatan organisasi atau pendapatan yang digunakan untuk itu makin besar.

4. Menciptakan keseimbangan dan keahlian, ini berarti bahwa pemberian kompensasi berhubungan dengan pensyaratan yang harus di penuhi oleh pegawai pada jabatan sehingga tercipta keseimbangan antara input (syarat-syarat) dan output.

\subsection{Kepuasan Kerja}

\subsubsection{Pengertian Kepuasan Kerja}

Berdasarkan Robbins dan Judge (2015: 170) disebutkan bahwa kepuasan kerja adalah suatu sikap umum terhadap pekerjaan seseorang sebagai perbedaan antara banyaknya ganjaran yang diyakini seharusnya diterima.Kepuasan kerja merupakan hal penting yang dimiliki individu dalam bekerja. Setiap individu pekerja memilki karakteristik yang berbeda-beda, maka tingkat kepuasan kerjanya pun berbeda-beda pula tinggi rendahnya kepuasan kerja 
tersebut dapat memberikan dampak yang tidak sama.

Menurut Lawler dan Boudreau (2015:180), ukuran kepuasan sangat didasarkan atas kenyataan yang dihadapi dan diterima sebagai kompensasi usaha dan tenaga yang diberikan.Kepuasan kerja tergantung kesesuaian atas keseimbangan antara yang diharapkan dengan kenyataan.

Menurut Priansa (2014:291) kepuasan kerja merupakan perasaan pegawai terhadap pekerjaannya, apakah senang/ suka atau tidak senang/ tidak suka sebagai hasil interaksi pegawai dengan lingkungan pekerjaannya atau sebagai presepsi sikap mental, juga sebagai penilaian pengawai terhadap pekerjaannya.Perasaan

pegawaiterhadap pekerjaannya mencerminkan sikap dan perilakunya dalam bekerja.

Kreitner dan Kinicki (2012: 502) menyatakan kepuasan kerja sebagai respons affective atau emosional terhadap berbagai segipekerjaan. Berdasarkan beberapa pengertian di atas maka dapat ditarik kesimpulan bahwa Kepuasan kerja adalah sikap seseorang dalam menghadapi pekerjaanya, seseorang yang memiliki kepuasan kerja yang tinggi akan memperlihatkan sikap yang positif terhadap pekerjaannya, sedangkan seseorang yang tidak puas akan memperlihatkan sikap yang negatif terhadap pekerjaan itu sendiri.

Menurut Sutrisno ( 2014 ;

112) Kepuasan kerja mengemukakan bahwa suatu sikap emosional yang menyenangkan dan mencintai pekerjaannya yang memberikan manfaat bagi kepentingan individu, perusahaan, dan masyarakat.

\subsubsection{Faktor-Faktor Kepuasan Kerja}

Kepuasan kerja merupakan hal yang penting, karena terbukti besar manfaatnya baik bagi kepentingan individu maupun organisasi itu sendiri.Bagi individu, penelitian tentang sebab-sebab dan sumber-sumber kepuasan kerja memungkinkan timbulnya usahausaha peningkatan kebahagiaan hidup mereka.Sedangkan bagi organisasi, penelitian mengenai kepuasan kerja dilakukan dalamrangka usaha peningkatan produksi dan pengurangan biaya melalui perbaikan sikap dan tingkah laku pegawainya.

Menurut As'ad dalam Priansa (2014;301) menyatakan faktor-faktor yang mempengaruhi kepuasan kerja adalah :

a. Faktor Psikologi

Merupakan faktor yang berhubungan dengan kejiwaan pegawai, yang meliputi: minat, kententraman dalam bekerja, sikap terhadap kerja, bakat dan ketrampilan.

b. Faktor Sosial

Merupakan faktor yang berhubungan dengan interaksi sosial, baik antara sesama pegawai, dengan atasannya maupun pegawai yang berbeda jenis pekerjaannya.

c. Faktor Fisik

Merupakan faktor yang berhubungan dengan kondisi fisik lingkungan kerja dan kondisi fisik pegawai, meliputi jenis pekerjaan, pengaturan waktu kerja dan istirahat, perlengkapan kerja, keadaan ruangan, suhu udara, penerangan, pertukaran udara, kondisi kesehatan pegawai, umur dan sebagainya. 
d. Faktor Finansial

Merupakan faktor yang berhubungan dengan jaminan serta kesejahteraan pegawai, yang meliputi sistem dan besarnya gaji atau upah, jaminan sosial, macammacam tunjangan, fasilitas yang diberikan, promosi dan sebagainya.

Menurut Kreitner dan Kinicki (2012: 504-505) terdapat lima faktor yang dapat memengaruhi timbulnya kepuasan kerja, yaitu sebagai berikut:

a. NeFulfillment (pemenuhan kebutuhan); Kepuasan ditentukan oleh tingkatan karakteristik pekerjaan memberikan kesempatan pada individu untuk memenuhi kebutuhannya.

b. Discrepancies (perbedaan); Kepuasan merupakan suatu hasil memenuhi harapan. Pemenuhan harapan mencerminkan perbedaan antara apa yang diharapkan dan yang diperoleh individu dari pekerjaan. Apabila harapan lebih besar daripada apa yang diterima, orang akan tidak puas. Sebaliknya diperkirakan individu akan puas apabila mereka menerima manfaar di atas harapan.

c. Value attainment (pencapaian nilai); Value attainment atau pencapaian nilai adalah bahwa kepuasan merupakan hasil dari persepsi pekerjaan memberikan pemenuhan nilai kerja individual yang penting.

d. Equity (keadilan); Kepuasan terdapat dari seberapa adil seorang individu di perlakukan di tempat nya bekerja.

e. Dispositional/ geneticcomponents (komponen genetik); Kepuasan kerja sebagian merupakan fungsi sifat pribadi dan faktor genetik.Perbedaan individu mempunyai arti penting dalam menentukan kepuasan kerja seperti halnya karakteristik lingkungan.

Faktor-faktor yang mempengaruhi kepuasan kerja, (Mangkunegara ,2013:120) yaitu:

a. Faktor pegawai yaitu; kecerdasan (IQ), kecakapan khusus, umur, jenis kelamin, kondisi fisik, pendidikan, pengalam kerja, masa kerja, kepribadian, emosi, cara berfikir, persepsi, dan sikap kerja.

b. Faktor pekerjaan yaitu; jenis pekerjaan, struktur organisasi, pangkat (golongan), kedudukan, mutu pengawasan, jaminan finansial, kesempatan promosi jabatan, interaksi social, dan hubungan kerja

\subsubsection{Indikator Kepuasan Kerja}

Indikator-indikator yang menentukan kepuasan kerja (Robbins, 2015: 181182):

1. Pekerjaan yang secara mental menantang

pegawai cenderung lebih menyukai pekerjaan yang memberi mereka kesempatan untuk menggunakan ketrampilan dan kemampuan mereka dan menawarkan beragam tugas, kebebasan, dan umpan balik. Pekerjaan yang terlalu kurang menantang akan menciptakan kebosanan,tetapi pekerjaan 
yang terlalu banyak menantang akan menciptakan frustasi dan perasaan gagal, kebanyakan karyawan akan mengalami kesenagan dan kepuasan.

2. Kondisi kerja yang mendukung

pegawai peduli akan lingkungan yang baik untuk kenyamanan pribadi maupun untuk mempermudahkan mengerjakan tugas yang baik. Studi-studi membuktikan bahwa pegawai lebih menyukai keadaan sekitar yang aman, tidak berbahaya dan tidak merepotkan.Disamping itu, kebanyakan pegawai lebih menyukai bekerja dekat dengan rumah, dalam fasilitas yang bersih dan relatif modern, dan dengan alat-alat yang memadai.

3. Gaji atau upah yang pantas Para pegawai menginginkan sistem upah dan kebijakan promosi yang mereka persepsikan sebagai adil dan segaris dengan penghargaan mereka. Bila upah diihat sebagai adil yang didasarkan pada tuntutan pekerjaan, tingkat ketrampilan individu, dan standar pengupahan komunitas, kemungkinan besar akan dihasilkan kepuasan. Promosi memberikan kesempatan untuk pertumbuhan pribadi, tanggung jawab yang lebih banyak, dan stasus sosial yang ditingkatkan.

4. Rekan kerja yang mendukung Bagi kebanyakan pegawai, bekerja juga mengisi kebutuhan akan interaksi sosial. Oleh karna itu, tidaklah mengejutkan apabila mempunyai rekan sekerja yang ramah dan mendukung akan mengarah ke kepuasan kerja yang meningkat. Perilaku atasan juga merupakan determinal utama dari kepuasan.

5. Pegawasan

Dengan melakukan

pegawasan yang baik oleh pimpinan maka dapat di ketahui kepuasan kerja seorang pegawai.

Menurut Rivai dan Sagala (2010:860), indikator kepuasan kerja seorang pegawai adalah sebagai berikut :

1. Isi pekerjaan

Berat ringannya suatu pekerjaan juga mempengaruhi kepuasan kerja pegawai.

2. Organisasi dan manajemen, organisasi juga dapat tolak ukur kepuasan kerja pegawai.

3. Kesempatan untuk maju

Memberi kesempatan bagi pegawai untuk meningkatkan karirnya di dalam suatu organisasi.

4. Gaji dan keuntungan dalam bidang financial

Pemberian kompensasi oleh pegawai harus di dasarkan pada asas keadilan dan kelayakan.

5. Rekan kerja

Kepuasan kerja juga dapat di pengaruhi oleh rekan kerja di dalam suatu lingkungan kerja.

6. Kondisi pekerjaan

Kondisi pekerjaan juga menjadi salah satu indikator kepuasan kerja, seorang pegawai akan merasa puas dalam bekerja jika di 
tempatkan pada posisi yang sesuai dengan keahlian nya.

Suparno (2015:19) memaparkan beberapa indikator sebuah organisasi yang memilki masalah mengenai ketidakpuasan kerja bagi pegawainya, yaitu :

1) Jumlah pegawai yang absen bertambah

2) Masuk kantor terlambat

3) Pulang dari kantor lebih cepat

4) Sering rebut antar pegawai

5) Mengabaikan atau mencelakakan pegawai lain

6) Pengambilan keputusan dan perilaku yang buruk

7) Terjadinya kecelakaan kerja yang tidak biasa

8) Bertambah pemborosan dan kerusakan alat

9) Terlibat masalah pelanggaran hukum

10) Penampilan yang semakin buruk

\subsection{Hipotesis Penelitian}

Berdasarkan latar belakang penelitian, rumusan masalah dan kerangka penelitian, maka hipotesis dalam penelitian ini adalah budaya organisasi dan kompensasi berpengaruh terhadap kepuasan kerja pegawai pada Dinas Pemberdayaan Masyarakat Gampong (DPMG) Kabupaten Pidie.

\section{METODE PENELITIAN}

\section{Teknik Pengumpulan Data}

\subsubsection{Data Primer}

Menurut Sigiyono (2017:47) data primer adalah data yang didapat dari sumber pertama baik dari individu atau perseorangan, seperti hasil wawancara atau suatu pengisian hasil kuesioner.

\subsubsection{Data Sekunder}

Menurut Sekaran (2007: 37) data Sekunder adalah data yang dikumpulkan melalui sumber seperti informasi rincian latar belakang perusahaan, catatan yang dipublikasi, arsip dan sumber-sumber lainnya. Informasi tertulis seperti kebijakan perusahaan, prosedur, dan aturan yang dapat diperoleh dari catatan dan dokumen organisasi. Sedangkan data sekunder lainnya berupa hasil statistik, publikasi pemerintah, informasi yang tersedia dari sumber publikasi atau non publikasi dari dalam atau luar organisasi, data penelitian sebelumnya, studi kasus dan dokumentasi perpustakaan, data online, website organisasi, data umum dari internet.

\subsection{Skala PengukuranVariabel}

Menurut Sugiyono (2010 : 132) skala likert digunakan untuk mengukur sikap, pendapat, dan persepsi seseorang atau kelompok orang tentang fenomena sosial. Data hasil penelitian yang diperoleh melalui penyebaran kuesioner dalam bentuk kualitatif dikomposisikan terlebih dahulu agar menjadi data kuantitatif. Adapun nilai kuantitatif yang dikomposisikan dilakukan dengan menggunakan Skala Likert dan untuk satu pilihan dinilai dengan jarak interval 1. Nilai dari pilihan tersebut antara lain : 1,2,3,4, dan 5 . Masing-masing pilihan tersebut dapat dilihat dalam tabel dibawah ini :

Tabel-III.1

Skala Likert

\begin{tabular}{|l|c|}
\hline \multicolumn{1}{|c|}{$\begin{array}{c}\text { Keterangan } \\
\text { (pilihan) }\end{array}$} & Skor \\
\hline Sangat Tidak Setuju & 1 \\
Tidak Setuju & 2 \\
Kurang Setuju & 3 \\
Setuju & 4 \\
Sangat Setuju & 5 \\
\hline
\end{tabular}




\subsection{Operasional Variabel}

Definisi variable adalah obyek penelitian atau apa yang menjadi titik perhatian suatu penelitian. Dalam penelitian ini digunakan sejumlah variable dependen (variable terikat). Definisi operasional masing-masing variable adalah sebagai berikut :

Tabel 3.2 Operasional Variabel

\begin{tabular}{|c|c|c|c|c|c|}
\hline Variabel & Definisi & Indikator & Ukuran & Ska & Item \\
\hline $\begin{array}{c}\text { Budaya } \\
\text { Organisa } \\
\text { si } \\
\left(\mathrm{X}_{1}\right)\end{array}$ & $\begin{array}{l}\text { Budaya } \\
\text { organisasi } \\
\text { adalah } \\
\text { seperangkat } \\
\text { asumsi atau } \\
\text { sistem } \\
\text { keyakinan, } \\
\text { nilai-nilai, } \\
\text { norma-norma } \\
\text { yang } \\
\text { dikembangkan } \\
\text { dalam } \\
\text { organisasi yang } \\
\text { dijadikan } \\
\text { pedoman } \\
\text { tingkah laku } \\
\text { bagi anggota- } \\
\text { anggotanya } \\
\text { untuk } \\
\text { mengatasi } \\
\text { masalah } \\
\text { adaptasi } \\
\text { eksternal dan } \\
\text { internal } \\
\text { Mangkunegara } \\
\text { (2011: 13) }\end{array}$ & 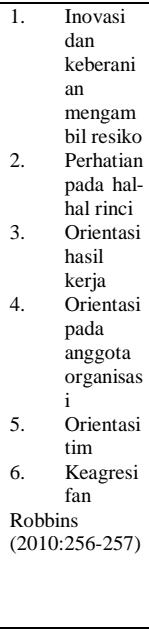 & $1-5$ & $\begin{array}{l}\text { Lik } \\
\text { ert }\end{array}$ & $\begin{array}{l}\text { X1.1 } \\
\text { X1.2 } \\
\text { X1.3 } \\
\text { X1.4 } \\
\text { X1.5 } \\
\text { X1.6 }\end{array}$ \\
\hline $\begin{array}{c}\text { Kompensas } \\
\text { i } \\
\left(\mathrm{X}_{2}\right)\end{array}$ & $\begin{array}{l}\text { Kompensasi } \\
\text { adalah semua } \\
\text { pendapatan } \\
\text { yang berbentuk } \\
\text { uang, barang } \\
\text { langsung atau } \\
\text { tidak langsung } \\
\text { yang diterima } \\
\text { pegawai } \\
\text { sebagai } \\
\text { imbalan atas } \\
\text { jasa yang } \\
\text { diberikan oleh } \\
\text { organisasi } \\
\begin{array}{l}\text { Malayu S.P } \\
\text { Hasibuan } \\
\text { (2012:118) }\end{array}\end{array}$ & 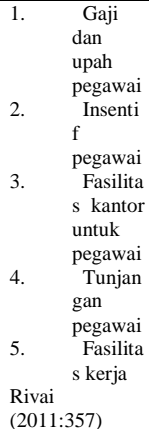 & $1-5$ & $\begin{array}{l}\text { Lik } \\
\text { ert }\end{array}$ & $\begin{array}{l}\mathrm{X} 2.1 \\
\mathrm{X} 2.2 \\
\mathrm{X} 2.3 \\
\mathrm{X} 2.4 \\
\mathrm{X} 2.5\end{array}$ \\
\hline $\begin{array}{c}\text { Kepuasa } \\
\text { n Kerja } \\
\text { (Y) }\end{array}$ & $\begin{array}{l}\text { Kepuasan kerja } \\
\text { adalah suatu } \\
\text { sikap umum } \\
\text { terhadap } \\
\text { pekerjaan } \\
\text { seseorang } \\
\text { sebagai } \\
\text { perbedaan } \\
\text { antara } \\
\text { banyaknya } \\
\text { ganjaran yang } \\
\text { diyakini } \\
\text { seharusnya } \\
\text { diterima.Kepua } \\
\text { san kerja } \\
\text { merupakan hal } \\
\text { penting yang } \\
\text { dimiliki } \\
\text { individu dalam } \\
\text { bekerja. Setiap } \\
\text { individu } \\
\text { pekerja } \\
\text { memilki } \\
\text { karakteristik } \\
\text { yang berbeda- } \\
\text { beda, maka } \\
\text { tingkat }\end{array}$ &  & $1-5$ & $\begin{array}{l}\text { Lik } \\
\text { ert }\end{array}$ & $\begin{array}{l}\text { Y1 } \\
\text { Y2 } \\
\text { Y3 } \\
\text { Y4 } \\
\text { Y5 }\end{array}$ \\
\hline
\end{tabular}

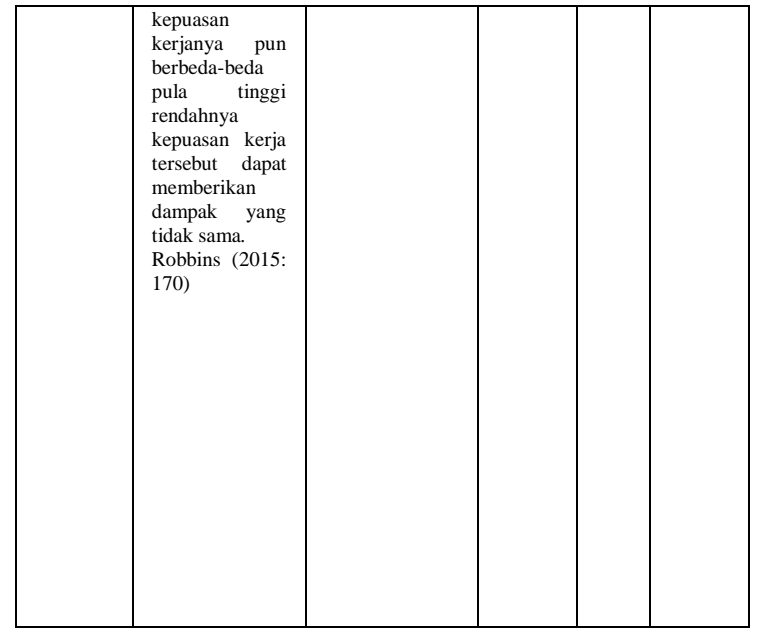

\subsection{Peralatan Analisis Data}

Analisis yang dilakukan dalam penelitian ini adalah analisis regresi berganda dengan menggunakan program SPSS. Analisis regresi, untuk menghitung besarnya pengaruh secara kuantitatif dari suatu perubahan kejadian (variabel $\mathrm{X}$ ) terhadap kejadian lainnya (variabel Y). Untuk melihat hubungan antara variabel yang dipergunakan rumus regresi berganda Umar (2013:256).

$$
\mathrm{Y}=\mathrm{a}+\mathrm{b}_{1} \mathrm{X}_{1}+\mathrm{b}_{2} \mathrm{X}_{2}+\mathrm{e}
$$

Dimana :

$$
\begin{array}{ll}
\mathrm{Y} & =\text { Kepuasan Pegawai } \\
\mathrm{a} & =\text { Konstanta } \\
\mathrm{b}_{1}, \mathrm{~b}_{2} & =\text { Koefisien regresi }
\end{array}
$$

variabel

$$
\begin{array}{ll}
\mathrm{X}_{1} & =\text { Budaya Organisasi } \\
\mathrm{X}_{2} & =\text { Kompensasi } \\
\mathrm{e} & =\text { error }
\end{array}
$$

\subsection{Pengujian Validitas dan Reliabilitas \\ 3.7.1 Uji Validitas}

Uji validitas digunakan untuk mengukur sah atau valid tidaknya suatu kuesioner. Suatu kuesioner dikatakan valid jika pertanyaan pada kuesioner mampu untuk mengungkap sesuatu yang akan diukur oleh kuesioner tersebut. (Ghozali, 2016 : 62). Pengujian validitas butir-butir 
dari kuesioner ini menggunakan metode korelasi product moment, dengan ketentuan jika koefisien korelasi (r) yang diperoleh > dari pada koefisien dari tabel nilai-nilai kritis r, yaitu pada taraf signifikan 5\% atau $1 \%$ instrumen tes yang diujicobakan tersebut dinyatakan valid.

\subsubsection{Uji Realibilitas}

Pengujian keandalan ditunjukkan untuk menguji sejauh mana hasil pengukuran dapat dipercaya. Tinggi rendahnya keandalan digambar melalui koefisien reliabilitas dalam suatu rangka tertentu. Dalam pengujian keandalan digunakan tes konsistensi internal yaitu sistem pengujian terhadap sekelompok tertentu, kemudian dihitung skornya dan diuji konsistensinya terhadap berbagai item yang ada dalam kelompok tersebut. Nilai koefisien alpha bervariasi mulai dari 0 (nol) sampai dengan 1 (satu) dan untuk nilai alphanya $=0,6$ atau kurang memberi indikasi bahwa alat ukur tersebut kurang keandalannya (Sugiyono, 2010 : 137).

\subsection{Pengujian Asumsi Klasik}

Uji Asumsi klasik ini dilakukan untuk mengetahui apakah modelestimasi yang dipergunakan memenuhi asumsi regresi linear klasik. Hal ini penting dilakukan agar diperoleh parameter yang valid dan handal. Uji diagnostic ini terdiri dari :

\subsubsection{Uji Normalitas}

Pengujian normalitas data dilakukan dengan melihat sebaran standarrized residual pada gambar normal P-P Plot yang menunjukkan bahwa sebaran standarrized residual berada dalam kisaran garis diagonal dan mempunyai probabilitas Kolmogorov Smirnov Z > 0,05.

\subsubsection{Uji Multikolinearitas}

Uji Multikolinearitas berkaitan dengan situasi dimana ada hubungan linear baik yang pasti atau mendekati pasti diantara variabel $\mathrm{X}$ atau independen. Uji ini menjelaskan model regresi yang baik yang seharusnya tidak terdapat korelasi diantara variabel independen. Apabila varaibel independen memiliki angka VIF (Varience Inflation Factor) lebih kecil dari 10, dan nilai toleransi lebih besar dari 0,10 maka dapat dikatakan tidak memiliki multikolinearitas (Ghozali, 2016 : 321).

\subsubsection{Uji Heteroskedastisitas}

Pengujian heteroskedastisitas bertujuan untuk menguji apakah dalam model regresi terjadi ketidaksamaan variance dari residual satu pengamatan ke pengamatan yang lain. Jika variance dari residual satu pengamatan ke pengamatan lain tetap maka disebut homoskedastisitas dan jika berbeda disebut heteroskedastisitas.

Model regresi yang baik adalah yang homokedastisitas atau tidak terjadi heteroskedastisitas. Deteksi ada tidaknya heteroskedastisitas dapat dilakukan dengan melihat ada tidaknya pola tertentu pada grafik scatter plot. Jika ada pola tertentu, seperti titik-titik yang ada membentuk pola tertentu yang teratur (bergelombang, melebar kemudian menyempit), maka mengidentifikasikan telah terjadi heteroskedastisitas.

\subsection{Pengujian Hipotesis}


Ho: Variabel-variabel bebas (Budaya Organisasi dan Kompensasi) tidak berpengaruh terhadap variable terikat KKepuasan kerja) Pegawai Dinas Pemberdayaan Masyarakat Gampong (DPMG) Kabupaten Pidie.

Ha: Adanya pengaruh variabelvariabel bebas (Budaya Organisasi dan Kompensasi) terhadap variable terikat (Kepuasan Kerja) Pegawai Dinas Pemberdayaan Masyarakat Gampong (DPMG) Kabupaten Pidie.

\subsubsection{Uji F (Secara Simultan)}

Selanjutnya Uji F yaitu untuk mengetahui apakah kedua variabel budaya organisasi dan kompensasi secara simultan berpengaruh terhadap kepuasan kerja pegawai, dengan ketentuan sebagai berikut :

1. Jika $F_{\text {hitung }}>F_{\text {tabel }}$ pada tingkat kepercayaan $95 \% \quad(\mathrm{a}=0,05)$, bahwa kedua variabel budaya organisasi dan kompensasi secara simultan mempengaruhi kepuasan kerja pegawai Dinas Pemberdayaan Masyarakat Gampong (DPMG) Kabupaten Pidie. Dengan demikian hipotesis nol (Ho) ditolak dan hipotesis alternatif (Ha) diterima.

2. Jika $F_{\text {hitung }}<\mathrm{F}_{\text {tabel }}$ pada tingkat kepercayaan $95 \%(a=0,05)$, bahwa kedua variabel budaya organisasi dan kompensasi secara simultan tidak mempengaruhi kepuasan kerja pegawai Dinas Pemberdayaan Masyarakat Gampong (DPMG) Kabupaten Pidie. Dengan demikian hipotesis nol (Ho) diterima dan hipotesis alternatif (Ha) ditolak.

\subsubsection{Uji t (Secara Parsial)}

Untuk menguji hipotesis

dalam penelitian ini penulis menggunakan Uji t yaitu pada tingkat keyakinan (convident interval 95\%) atau tingkat kesalahannya (alpha) a sebesar 0,05.

1. Jika $t_{\text {hitung }}>t_{\text {tabel }}$ tingkat kepercayaan $95 \% \quad(a=0,05)$, bahwa variabel budaya organisasi dan kompensasi secara parsial berpengaruh terhadap kepuasan kerja pegawai Dinas Pemberdayaan Masyarakat Gampong (DPMG) Kabupaten Pidie. Dengan demikian hipotesis nol (Ho) ditolak dan hipotesis alternatif (Ha) diterima.

2. Jika $t_{\text {hitung }}<t_{\text {tabel }}$ pada tingkat kepercayaan $95 \% \quad(a=0,05)$, bahwa variabel budaya organisasi dan kompensasi secara parsial tidak berpengaruh terhadap kepuasan kerja pegawai Dinas Pemberdayaan Masyarakat Gampong (DPMG) Kabupaten Pidie. Dengan demikian hipotesis nol (Ho) diterima dan hipotesis alternatif (Ha) ditolak.

\section{HASIL PENELITIAN DAN PEMBAHASAN}

\subsection{Karakteristik Responden}

Karakteristik responden dilihat dari, jenis kelamin, usia, pendidikan terakhir, status perkawinan, dan penghasilan perbulan. Adapun jumlah responden dalam penelitian ini adalah 41 orang. karakteristik responden dapat dilihat pada tabel 4.1 berikut:

Tabel 4.1

Karakteristik Responden

\begin{tabular}{|c|l|c|c|}
\hline No & Karakteristik & Frekuensi & Persentase (\%) \\
\hline $\mathbf{1}$ & Jenis Kelamin & 28 & $68.3 \%$ \\
& Laki-laki & 13 & $31.7 \%$ \\
& Perempuan & & \\
\hline & & & $\mathbf{1 0 0 \%}$ \\
\hline
\end{tabular}




\begin{tabular}{|c|c|c|c|}
\hline 2 & $\begin{array}{l}\text { Usia } \\
\text { 20-29 Tahun } \\
\text { 30-39 Tahun } \\
\text { 40-45 Tahun } \\
>45 \text { Tahun }\end{array}$ & $\begin{array}{c}1 \\
16 \\
9 \\
15\end{array}$ & $\begin{array}{l}2.4 \% \\
39.0 \% \\
22.0 \% \\
36.6 \%\end{array}$ \\
\hline \multicolumn{2}{|c|}{ TOTAL } & 41 & $100 \%$ \\
\hline 3 & $\begin{array}{l}\text { Pendidikan } \\
\text { Terakhir } \\
\text { SMA } \\
\text { D3 } \\
\text { Sarjana } \\
\text { Pasca Sarjana } \\
\end{array}$ & $\begin{array}{c}1 \\
4 \\
32 \\
4\end{array}$ & $\begin{array}{l}2.4 \% \\
9.8 \% \\
78.0 \% \\
9.8 \%\end{array}$ \\
\hline \multicolumn{2}{|r|}{ TOTAL } & 41 & $100 \%$ \\
\hline 4 & $\begin{array}{l}\text { Status } \\
\text { Perkawinan } \\
\text { Belum Menikah } \\
\text { Menikah }\end{array}$ & $\begin{array}{c}2 \\
39\end{array}$ & $\begin{array}{c}4.9 \% \\
9.51 \%\end{array}$ \\
\hline \multicolumn{2}{|r|}{ TOTAL } & 41 & $100 \%$ \\
\hline 5 & 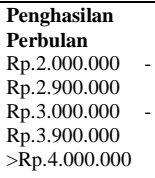 & $\begin{array}{l}14 \\
12 \\
15\end{array}$ & $\begin{array}{l}34.1 \% \\
29.3 \% \\
36.6 \%\end{array}$ \\
\hline & TOTAL & 41 & $100 \%$ \\
\hline
\end{tabular}

Sumber: Output SPSS, 2020 (Diolah)

Hasil analisis data pada tabel

4.1 dilihat dari jenis kelamin responden diketahui laki-laki sebanyak 28 orang dan perempuan hanya 13 orang. Dengan demikian maka dapat disimpulkan, pegawai pada Dinas Pemberdayaan Masyarakat Gampong Kabupaten Pidie lebih didominasi oleh pegawai laki-laki.

Selanjutnya karakteristik mengenai tingkatan usia responden. Responden yang berusia 20-29 tahun 1 orang, yang berusia 30-39 tahun 16 orang, kemudian yang berusia 40-45 tahun 9 orang dan yang berusia di atas 45 tahun sebanyak 15 orang. Dengan demikian maka dapat disimpulkan bahwa pegawai pada Dinas Pemberdayaan Masyarakat Gampong Kabupaten Pidie lebih didominasi oleh pegawai berusia 3039 tahun.

Selanjutnya karakteristik mengenai status pernikahan. Responden yang sudah menikah sebanyak 39 orang, dan yang belum menikah sebanyak 2 orang. Dengan demikian maka dapat disimpulkan bahwa pegawai pada Dinas
Pemberdayaan Masyarakat Gampong Kabupaten Pidie lebih didominasi oleh pegawai yang sudah menikah.

Selanjutnya dilihat dari segi tingkat pendidikan, dimana responden yang berpendidikan SMA sederajat 1 orang, D3 sebanyak 4, sarjana 32 orang, dan pasca sarjana sebanyak 4 orang. Dengan demikian maka dapat disimpulkan bahwa pegawai pada Dinas Pemberdayaan Masyarakat Gampong Kabupaten Pidie lebih didominasi oleh pegawai yang berpendidikan Sarjana.

Selanjutnya dilihat dari segi status pernikahan, diketahui bahwa pegawai yang sudah menikah sebanyak 39 orang dan yang belum menikah sebanyak 2 orang. Dengan demikian maka dapat disimpulkan bahwa Pegawai pada Dinas Pemberdayaan Masyarakat Gampong Kabupaten Pidie lebih didominasi oleh pegawai yang sudah menikah.

Selanjutnya karakteristik responden juga dilihat dari segi ratarata penghasilan perbulan, dimana diketahui pegawai yang berpenghasilan Rp. 2.000,000-Rp. 2.900,000 sebanyak 14 orang, pegawai yang berpenghasilan Rp.3.000,000-Rp. $\quad 3.900,000$ sebanyak 12 orang dan pegawai yang berpenghasilan > Rp, 4.000,000 sebanyak 15 orang. Dengan demikian maka dapat disimpulkan bahwa ratarata pegawai pada Dinas Pemberdayaan Masyarakat Gampong Kabupaten Pidie berpenghasilan > Rp4,000,000 per bulan.

\subsubsection{Frekuensi Rerata Jawaban Responden}

Tabel 4.2

Pertanyaan Budaya Organisasi (X1)

\begin{tabular}{|c|l|c|c|c|c|c|c|}
\hline \multirow{2}{*}{ No } & Pertanyaan & \multicolumn{5}{|c|}{ Frekwensi Skor } & \multirow{2}{*}{$\begin{array}{c}\text { rata } \\
\text { rata }\end{array}$} \\
\cline { 2 - 7 } X1.1 & $\begin{array}{l}\text { Pimpinan } \\
\text { mendorong } \\
\text { saya untuk } \\
\text { melakukan }\end{array}$ & 0 & 3 & 11 & 22 & 5 & $\mathbf{3 , 7 1}$ \\
\hline
\end{tabular}




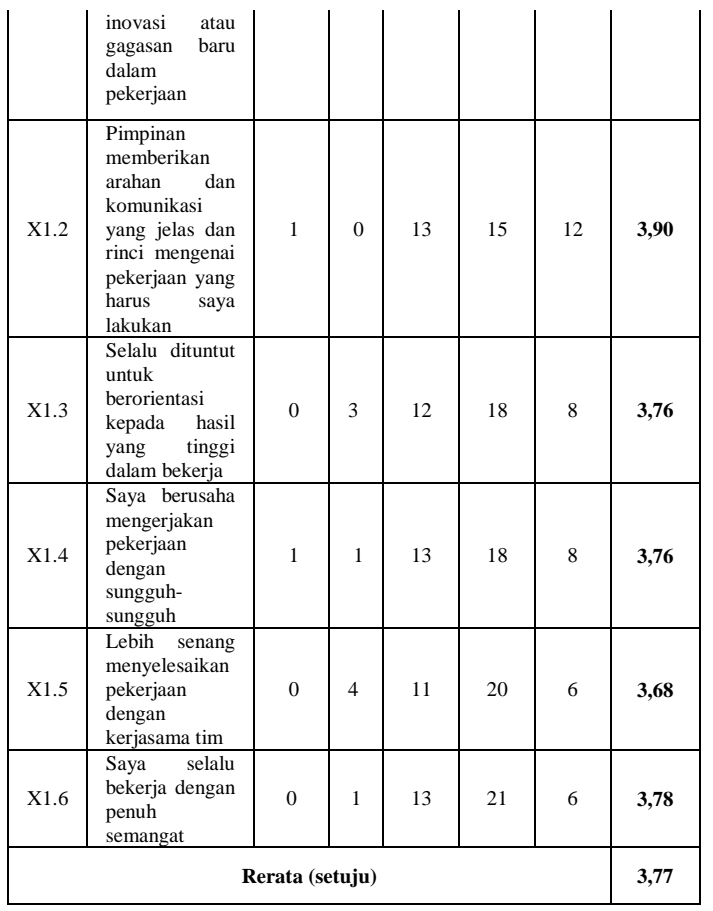

Sumber: Output SPSS, 2020 (Diolah)

Berdasarkan frekuensi rerata tersebut di atas menunjukan bahwa seluruh item indikator untuk variabel budaya organisasi (X1) diperoleh rerata diperoleh sebesar 3,77 dengan demikian maka dapat disimpulkan, rata-rata responden menjawab setuju untuk semua pertanyaan budaya organisasi berpengaruh terhadap kepuasan kerja pada Dinas Pemberdayaan Masyarakat Dan Gampong Kabupaten Pidie.

Tabel 4.3

Pertanyaan Kompensasi (X2)

\begin{tabular}{|c|c|c|c|c|c|c|c|c|c|c|c|c|c|c|c|}
\hline \multicolumn{8}{|c|}{$\begin{array}{c}\text { Iavel } 4.5 \\
\text { Pertanyaan Kompensasi (X2) }\end{array}$} & & \multirow{3}{*}{$\begin{array}{l}\text { Gaji yang } \\
\text { saya terima } \\
\text { seimbang } \\
\text { dengan tugas } \\
\text { yang saya } \\
\text { kerjakan } \\
\text { setiap bulan }\end{array}$} & \multirow{3}{*}{0} & \multirow{3}{*}{3} & \multirow{3}{*}{9} & \multirow{3}{*}{22} & \multirow{3}{*}{7} & \multirow{3}{*}{3,80} \\
\hline \multirow{2}{*}{ No } & \multirow{2}{*}{ Pertanyaan } & \multicolumn{5}{|c|}{ Frekwensi Skor } & \multirow{2}{*}{$\begin{array}{l}\text { rata } \\
\text { rata }\end{array}$} & \multirow[t]{2}{*}{$\mathrm{Y}$} & & & & & & & \\
\hline & & STS & TS & KS & $\mathbf{S}$ & SS & & & & & & & & & \\
\hline $\mathrm{X} 2.1$ & $\begin{array}{l}\text { Saya } \\
\text { mendapatka } \\
\text { gaji atas } \\
\text { pekerjaan saya } \\
\text { setiap bulan } \\
\text { secara tepat } \\
\text { waktu } \\
\end{array}$ & 0 & 4 & 9 & 22 & 6 & 3,73 & $\mathrm{Y} 4$ & $\begin{array}{l}\text { Rekan kerja } \\
\text { memberikan } \\
\text { bantuan } \\
\text { langsung } \\
\text { dalam } \\
\text { menyelesaik } \\
\text { an pekerjaan }\end{array}$ & 0 & 2 & 10 & 23 & 6 & $\mathbf{3 , 8 0}$ \\
\hline $\mathrm{X} 2.2$ & $\begin{array}{l}\text { Kantor saya } \\
\text { memberikan } \\
\text { insentif atau } \\
\text { bonus apabila } \\
\text { saya telah } \\
\text { menyelesaikan } \\
\text { pekerjaan } \\
\text { sesuai target } \\
\text { (selain gaji). }\end{array}$ & 0 & 0 & 13 & 16 & 12 & 3,98 & $\mathrm{Y} \$$ & $\begin{array}{l}\text { Atasan } \\
\text { dalam } \\
\text { menilai } \\
\text { prestasi } \\
\text { kerja } \\
\text { pegawai } \\
\text { secara } \\
\text { obyektif } \\
\end{array}$ & 0 & 4 & 9 & 24 & 4 & 3,68 \\
\hline & $\begin{array}{l}\text { Pimpinan akan } \\
\text { memberikan }\end{array}$ & & & & & & & & \multicolumn{6}{|c|}{ Rerata (setuju) } & 3,77 \\
\hline
\end{tabular}

$\mathrm{X} 2.3 \quad \begin{aligned} & \text { memberikan } \\ & \text { penghargaa }\end{aligned}$

\begin{tabular}{l|l}
$\mathrm{X} 2.3$ & $\begin{array}{l}\text { kepada } \\
\text { pegawai yang }\end{array}$ \\
beprastan
\end{tabular} pegawai yan
berprestasi tinggi

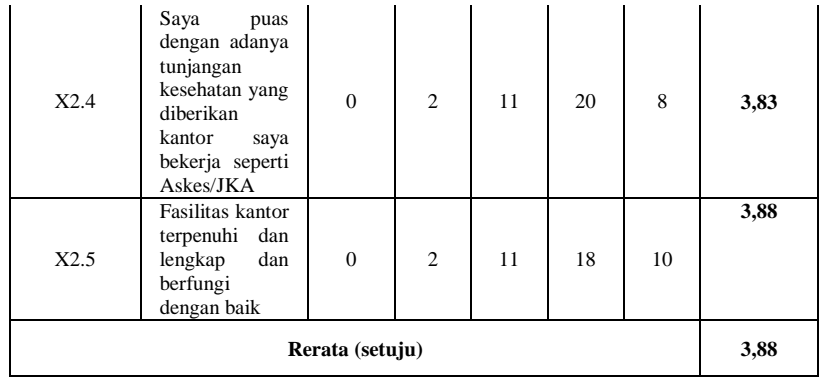

Hasil untuk item pertanyaan kompensasi (X2) diperoleh rerata sebesar 3,88. Dengan demikian maka dapat disimpulkan, rata-rata reponden dalam penelitian ini menjawab setuju untuk semua pertanyaan varibel kompensasi pegawai pada pada Dinas Pemberdayaan Masyarakat Dan Gampong Kabupaten Pidie.

\section{Tebel 4.4}

\section{Pertanyaan Kepuasan Kerja (Y)}

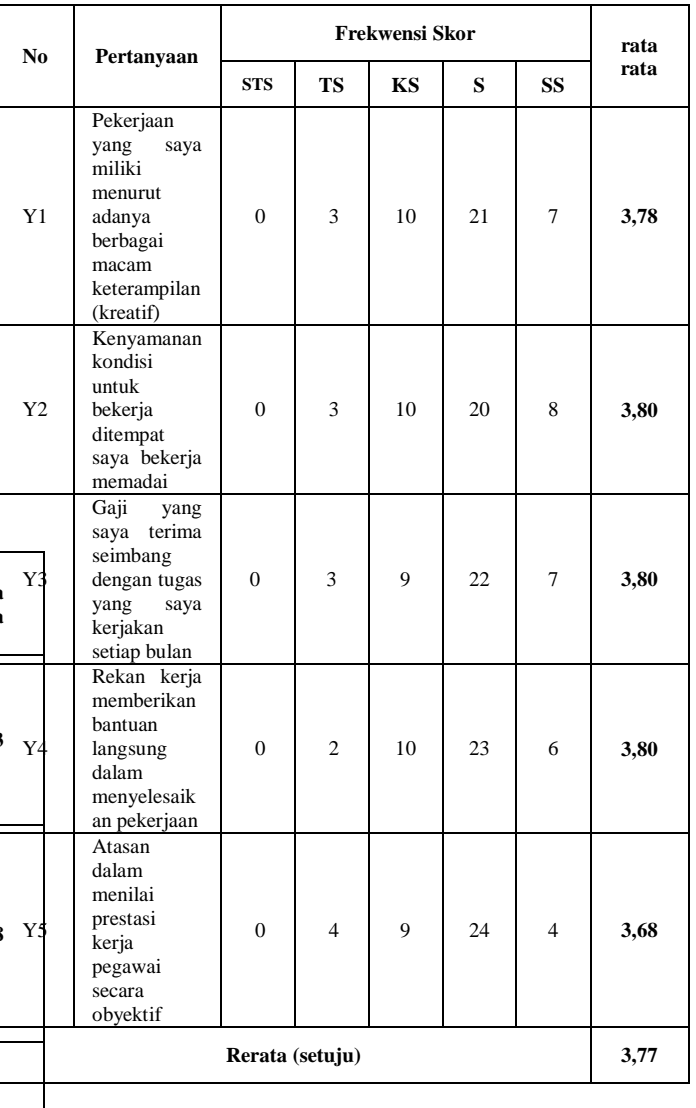
sebesar 3,77. Dengan demikian maka kepuasan kerja diperoleh rerata 
dapat disimpulkan, rata-rata reponden dalam penelitian ini menjawab setuju untuk semua pertanyaan variabel kepuasan kerja pada pada Dinas Pemberdayaan Masyarakat Dan Gampong Kabupaten Pidie.

\subsection{Pengujian Validitas dan Reliabilitas}

\subsubsection{Hasil Uji Validitas}

Teknik pengujian validitas data menggunakan teknik korelasi product moment dari pearson dengan tingkat signifikan 5\% untuk mengetahui keeratan pengaruh antara variabel bebas dengan variabel terikat. Uji vadilitas adalah untuk melihat kebenaran dari hasil jawaban responden dengen menbanding koefisien korelasi dengan nilai kritis. Apabila nilai total pearson correlation > atau probabilitas kurang dari nilai r-tabel, maka item tersebut valid. Uji validitas dapat dilihat pada tabel dibawah ini.

Tabel 4.5

Hasil Pengujian Validitas Data
0,308 lebih besar dari nilai Koefesien Korelasi (r-tabel) untuk semua variabel, dengan demikian dapat disimpulkan bahwa semua koesioner yang diberikan pernyataan oleh responden dapat dilanjutkan untuk pengelolahan selanjutnya, artinya pernyataan tersebut semua valid.

\subsubsection{Hasil Pengujian Reliabilitas}

Reliabilitas (keandalan)

merupakan suatu ukuran kestabilan dan konsistensi responden dalam menjawab hal yang berkaitan dengan item-item pernyataan. Suatu kuesioner dinyatakan rilialibel atau handal Reliliabel jika memberikan nilai cronbach Alpha>0,60. Dibawah ini disajikan tabel 4.3 hasil reliabilitas dengan bantuan SPSS diperoleh sebagai berikut.

Tabel 4.6

\section{Hasil Pengujian Reliabilitas}

\begin{tabular}{|l|l|c|c|c|}
\hline No & Variabel & $\begin{array}{c}\text { Jumlah } \\
\text { Item }\end{array}$ & $\begin{array}{c}\text { Nilai } \\
\text { Alpha }\end{array}$ & Keterangan \\
\hline 1. & Budaya & & & \\
& Organisasi & 6 & 0.836 & Handal \\
2. & Kompensasi & 5 & 0.764 & Handal \\
3. & Kepuasan & 5 & 0.845 & Handal \\
& kerja & & & \\
\hline
\end{tabular}

Sumber: Output SPSS, 2020 (Diolah) Berdasarkan tabel diatas, diketahui bahwa nilai r-tabel sebesar
Sumber: Output SPSS 2020 (Diolah)

Keterang an

Dari tabel 4.6 di atas maka dapat diketahui Cronbach Alpha valid asing-masing variabel penelitian Valdebih besar dari 0,60. Dengan Validemikian, kuesioner yang digunakan Validntuk pengumpulan data dinilai sudah Valighenunjukkan kehandalan atau Valkonsistensi dan dapat dilanjutkan Validntuk pengelolahan data regresi.

Valid

Valid Vali4.3. Valiklasik Hasil Pengujian Asumsi Vali4.3.1. Hasil Uji Normalitas

Valid
Valid
Uji normalitas digunakan untuk menguji data dari sampel yang diambil normal ataupun tidak. Sampel yang difokuskan dalam 
penelitian terlihat semuanya aktif dan berfungsi dalam memberikan pernyataan melalui kuesioner yang diberikan. Residual variabel yang terdistribusi normal yang terletak disekitar garis horizontal (tidak terpisah jauh dari diagonal).Berdasarkan $P$-plot pada lampiran menunjukkan sebaran standardized residual berada dalam kisaran garis diagonal. Metode yang lebih handal adalah dengan melihat normal probability plot yang membandingkan distribusi kumulatif dari distribusi normal, yaitu sebagaimana terlihat pada gambar 4.1 dibawah ini.

\section{Gambar 4.1 \\ Normalitas P-P Plot Regression (Uji Normalitas)}

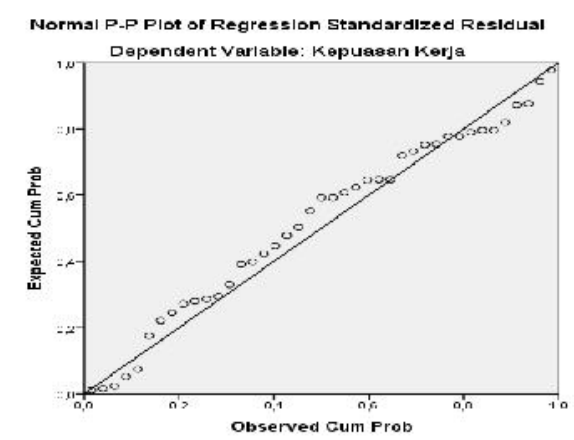

Berdasarkan Gambar 4.1, dapat dilihat bahwa garis yang menggambarkan data sesungguhnya mengikuti garis diagonal. Dengan demikian dapat diartikan bahwa data yang digunakan dalam penelitian ini terdistribusi secara normal.

Pengujian normalitas juga dapat dilakukan dengan menggunakan teknik Kolmogorov Smirnov. Pada pengujian Kolmogorov Smirnov nilai Asymp Sig. (2-tailed) yang diisyaratkan adalah di atas 0,05.

Tabel 4.7

Hasil Uji normalitas KolmogorovSmirnov

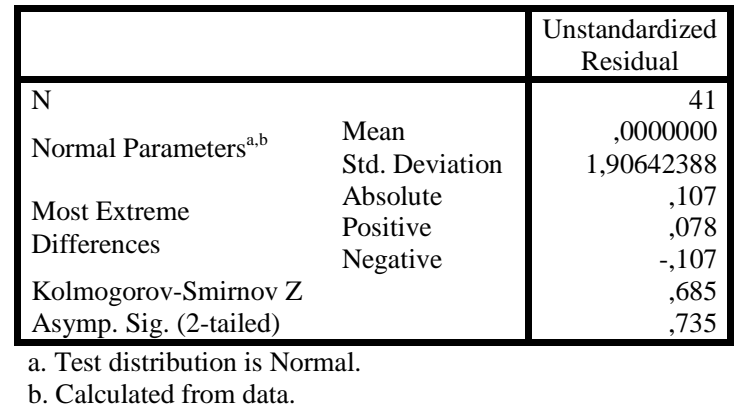

Berdasarkan output di atas, diketahui bahwa nilai signifikan dalam model ini sebesar 0.735 lebih besar dari 0.05, sehingga dapat disimpulkan bahwa data yang digunakan dalam penelitian ini berdistribusi normal.

\subsubsection{Hasil Uji Multikolinearitas}

Gejala multikolineritas menunjukan terjadinya hubungan yang signifikan antara sesama variabel indipenden. Regresi linier berganda mengisyaratkan tidak adanya gejala tersebut. hal ini disebabkan, apabila terjadi gejala multikolonieritas, maka perubahan suatu variabel indipenden tidak hanya berdampak perubahan variabel independen lainnya, sehingga besarnya pengaruh masing-masing variabel independen sulit diketahui secara pasti. Untuk mengetahui ada atau tidaknya gejala multikolonieritas dilihat dari nilai tolerance dan VIF seperti terlihat dalam tabel 4.6 sebagai berikut:

Tabel 4.8

Nilai VIF Variabel Independen

\begin{tabular}{|c|l|c|c|c|}
\hline No & Variabel & $\begin{array}{c}\text { Toler } \\
\text { ance }\end{array}$ & $\begin{array}{c}\text { Nila } \\
\text { i } \\
\text { VIF }\end{array}$ & \\
\hline 1 & Budaya Organisasi & 0,4 & 2, & Keterangan \\
. & & 77 & 09 & Multikolinearitas \\
2 & Kompensasi & 0,4 & 6 & Non \\
. & & 77 & 2, & Multikolinearitas \\
& & & 09 & \\
& & & 6 & \\
\hline
\end{tabular}

Sumber: Output SPSS 2020 (Diolah) 
Berdasarkan tabel 4.6 di atas dapat dilihat pada nilai tolerance dari kedua variabel yang lebih besar dari 0,1 . Hasil penghitungan VIF juga menunjukkan bahwa nilai VIF masing-masing variabel kurang dari 10. Jadi dapat disimpulkan bahwa tidak adanya pengaruh multikolinearitas antar variabel bebas dalam model regresi.

\subsubsection{Hasil Uji Heteroskedastisitas}

Deteksi ada tidaknya heteroskedastisitas yaitu dengan melihat ada atau tidaknya pola tertentu pada grafik scatterplot. Jika ada pola tertentu, seperti titik-titik yang ada membentuk pola tetentu yang teratur (bergelombang, melebar kemudian menyempit), maka mengidentifikasikan telah terjadi heteroskedastisitas. Jika tidak ada pola yang jelas, serta titik-titik menyebar diatas dan dibawah angka 0 pada sumbu Y maka tidak terjadi heteroskedastisitas. Hasil pengolahan data menunjukkan grafik scatterplot seperti terlihat pada gambar berikut ini :

Gambar 4-2:

\section{Hasil Uji Heterokedastisitas}

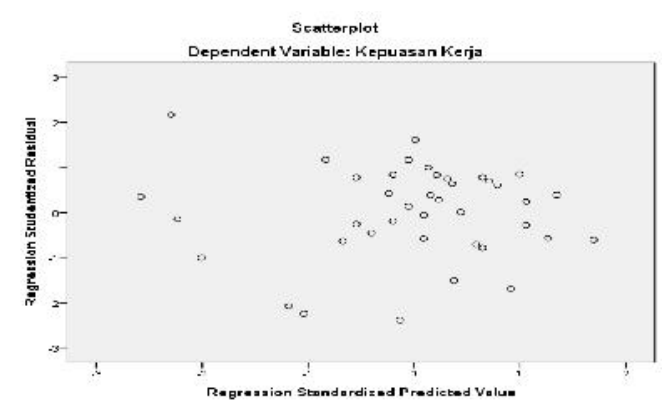

Berdasarkan hasil pengujian seperti terlihat pada Gambar $4.2 \mathrm{di}$ atas dapat dijelaskan bahwa model regresi dalam penelitian ini tidak terjadi heteroskedastisitas, seperti yang telah dikemukan sebelumnya atau dengan kata lain sesuai dengan pendapat sebelumnya.

\subsection{Analisis Pengaruh Budaya organisasi dan Kompensasi terhadap Kepuasan Kerja}

Untuk mengetahui pengaruh budaya organisasi dan kompensasi terhadap kepuasan kerja, maka digunakan metode regresi linier berganda. Hal ini ditunjukan oleh nilai koefesien regresi masing-masing variabel seperti terlihat dalam bagian output SPSS di bawah ini.

Tabel 4.9

Hasil Regresi Linier Berganda

\begin{tabular}{|c|c|c|c|c|c|c|c|}
\hline \multicolumn{8}{|c|}{ Coefficients $^{a}$} \\
\hline \multirow[t]{2}{*}{ Model } & \multicolumn{2}{|c|}{$\begin{array}{l}\text { Unstandardized } \\
\text { Coefficients }\end{array}$} & \multirow{2}{*}{$\begin{array}{c}\text { Stand } \\
\text { ardize } \\
d \\
\text { Coeffi } \\
\text { cients } \\
\text { Beta }\end{array}$} & \multirow[t]{2}{*}{$T$} & \multirow[t]{2}{*}{$\begin{array}{l}\mathrm{Si} \\
\mathrm{g} .\end{array}$} & \multicolumn{2}{|c|}{$\begin{array}{c}\text { Collinearity } \\
\text { Statistics }\end{array}$} \\
\hline & B & \begin{tabular}{|c} 
Std. \\
Erro \\
$r$
\end{tabular} & & & & $\begin{array}{l}\text { Toler } \\
\text { ance }\end{array}$ & VIF \\
\hline (Constant) & 2,034 & $\begin{array}{c}2,11 \\
6\end{array}$ & & $\begin{array}{l}, 9 \\
61\end{array}$ & $\begin{array}{l}, 3 \\
42\end{array}$ & & \\
\hline $\begin{array}{l}\text { Budaya } \\
\text { Organisasi }\end{array}$ & ,361 & , 135 & ,379 & $\begin{array}{c}2, \\
66 \\
9\end{array}$ & $\begin{array}{l}0 \\
11\end{array}$ & ,477 & $\begin{array}{r}2,0 \\
96\end{array}$ \\
\hline Kompesasi &, 519 & ,154 & ,479 & $\begin{array}{c}3, \\
37 \\
5\end{array}$ & $\begin{array}{l}0 \\
02\end{array}$ & ,477 & $\begin{array}{l}2,0 \\
96\end{array}$ \\
\hline
\end{tabular}

Sumber: Output SPSS 2020 (Diolah)

Berdasarkan hasil perhitungan regresi pada bagian output SPSS di atas maka persamaan regresi yang memperlihatkan kepuasan kerja sebagai fungsi dari budaya organisasi dan kompensasi dapat diformulasikan sebagai berikut : $0.519 X^{2}$$$
Y=2,034+0.361 X^{1}+
$$

Dari hasil Tabel persamaan regresi linier berganda di atas, maka dapat diketahui bahwa nilai konstanta sebesar 2,034 dengan taraf signifikan sebesar 0,342 dibawah 0,05, artinya jika variabel independen yaitu budaya organisasi dan kompensasi dianggap konstan (tetap), maka kepuasan kerja sebesar 2,034.

Hasil pengujian untuk variabel budaya organisasi diperoleh nilai koefisien regresi yang pada itif 
yaitu sebesar 0.361 dengan taraf signifikan 0,011 dibawah 0,05, setiap adanya peningkatan budaya organisasi sebesar $1 \%$, maka akan menigkatkan kepuasan kerja sebesar $0,361 \%$. Artinya semakin baik budaya organisasi pada Dinas Pemberdayaan Masyarakat Gampong Kabupaten Pidie maka semakin meningkat kepuasan kerja pegawai.

Hasil pengujian untuk variabel kompensasi diperoleh nilai koefisien regresi 0.519 dengan taraf signifikan sebesar 0.002 dibawah 0.05. Dengan demikian dapat dikatakan bahwa setiap $1 \%$ adanya peningkatan kompensasi maka akan menigkatkan kepuasan kerja sebesar 0,519\%. Jadi semakin bagus kompensasi pegawai pada Dinas Pemberdayaan Masyarakat Gampong, maka semakin banyak pegawai yang akan merasa puas.

\subsection{Analisis Korelasi (R) dan Determinasi $\left(\mathbf{R}^{\mathbf{2}}\right)$} korelasi (hubungan) variabel independen terhadap variabel dependen maka digunakan koefesien korelasi (R). Menurut Sugiyono (2017:142) pedoman untuk memberikan interprestasi koofesien korelasi (hubungan) sebagai berikut :
a. $0,00-0,199=$ sangat rendah
b. $0,20-0,399=$ rendah
c. $0,40-0,599=$ sedang
d. $0,60-0,799=$ kuat
e. $0,80-1,000=$ sangat kuat
Sedangkan untuk melihat

besarnya determinasi (pengaruh) variabel independen secara simultan terhadap variabel dependen digunakan koefisien determinasi $\left(\mathrm{R}^{2}\right)$. Untuk lebih jelas bisa di lihat pada Tabel berikut ini:
Tabel 4.10

Nilai Koefisien Korelasi (R) dan Koefisien Determinasi $\left(R^{2}\right)$

Model Summary ${ }^{\mathrm{b}}$

\begin{tabular}{|c|c|c|c|c|}
\hline Model & $R$ & $\begin{array}{c}\mathrm{R} \\
\text { Square }\end{array}$ & $\begin{array}{c}\text { Adjusted } \\
\mathrm{R} \\
\text { Square }\end{array}$ & $\begin{array}{c}\text { Std. } \\
\text { Error of } \\
\text { the } \\
\text { Estimate }\end{array}$ \\
\hline 1 &, $797^{\mathrm{a}}$ &, 635 &, 616 & 1,956 \\
\hline
\end{tabular}

Sumber: Output SPSS, 2020

Tabel diatas menunjukkan nilai koefisien korelasi $\mathrm{R}$ menunjukkan hubungan antara variabel independen terhadap variabel dependen tergolong kuat karena nilainya sebesar 0.797 mendekati angka $+1,000$.

Sedangkan untuk koefisien determinasi $\left(\mathrm{R}^{2}\right)$ diperoleh nilai 0.635 , artinya besarnya variasi pengaruh budaya organisasi dan kompensasi terhadap kepuasan kerja sebesar $63,5 \%$ sedangkan sisanya sebesar $36,5 \%$ dipengaruhi oleh variabel lain yang tidak ditelitu pada penelitian ini.

\subsection{Hasil Uji Hipotesis}

Ho: Tidak ada pengaruh budaya organisasi dan kompensasi terhadap kepuasan kerja pada Dinas Pemberdayaan Masyarakat Gampong.

$\mathrm{Ha}$ : Adanya pengaruh budaya organisasi dan kompensasi terhadap kepuasan kerja pada Dinas Pemberdayaan Masyarakat Gampong.

4.5.1.1 Pembuktian Hipotesis
Secara Silmultan (Uji F)
Pengujian hipotesis secara
simultan dilakukan untuk
membuktikan bahwa benar adanya
pengaruh variabel independen
terhadap variabel dependen sebagai
mana sudah dijelakan di atas. Untuk


lebih jelas hasil Uji - F dapat dilihat pada Tabel 4.11 berikut :

Tabel 4.11

Hasil Pengujian Secara Simultan (Uji-F)

ANOVA $^{a}$

\begin{tabular}{|l|c|c|c|c|c|}
\hline Model & $\begin{array}{c}\text { Sum } \\
\text { of } \\
\text { Squar } \\
\text { es }\end{array}$ & $\begin{array}{c}\text { D } \\
f\end{array}$ & $\begin{array}{c}\text { Mean } \\
\text { Squar } \\
\text { e }\end{array}$ & F & Sig. \\
\hline Regressi & 253,0 & 2 & 126,5 & 33,0 &, 00 \\
on & 12 & 06 & 67 & $0^{\mathrm{b}}$ \\
1 Residual & 145,3 & 3 & 3,826 & & \\
78 & 8 & & & \\
Total & 398,3 & 4 & & & \\
90 & 0 & & & \\
\hline
\end{tabular}

Sumber: Data Output SPSS, 2020

(Diolah).

Dari hasil perhitungan pada Tabel 4.11 di atas, diperoleh $F_{\text {hitung }}$ 33,067 dengan tingkat probabilitas 0,00 , sedangkan $F_{\text {tabel }}$ sebesar 3,245. Karena probabilitas jauh lebih kecil dari $0,05 . F_{\text {hitung }}$ lebih besar dari $F_{\text {tabel }}$ maka dapat dikatakan bahwa benar variabel kepuasan kerja dipengaruhi secara simultan (bersama-sama) dan signifikan oleh budaya organisasi dan kompensasi pada Dinas Pemberdayaan Masyarakat Gampong Kabupaten Pidie.

\subsubsection{Pembuktian Hipotesis Secara Parsial (Uji t) \\ Untuk membuktikan} bahwasanya benar adanya pengaruh masing-masing variabel budaya organisasi dan kompensasi terhadap kepuasan kerja, maka dilakukan pembuktian dengan Uji Statistik secara parsial (uji t) dengan demikian maka dapat disimpulkan bahwa variabel yang dimasukkan kedalam metode regresi secara parsial dapat dijelaskan pada persamaan regresi berikut:

1. Hasil penelitian terhadap pengaruh budaya organisasi diperoleh nilai $t_{\text {hitung }} 2,669$ sedangkan untuk nilai $t_{\text {tabel }} 2,02$.

Karena nilai $t_{\text {hitung }}$ lebih besar dari $t_{\text {tabel }}$ dengan tingkat signifikan sebesar 0.011 lebih kecil dari 0,05 dapat disimpulkan bahwa budaya organisasi memiliki pengaruh secara parsial dan signifikan terhadap kepuasan kerja pada Dinas Pemberdayaan Masyarakat Gampong.

2. Selanjutnya hasil penelitian terhadap pengaruh kompensasi diperoleh nilai $t_{\text {hitung }} 3,375$ sedangkan untuk nilai $t_{\text {tabel }} 2,02$. Karena nilai $t_{\text {hitung }}$ lebih besar dari $t_{\text {tabel }}$ dengan probabilitasnya sebesar 0.002 lebih kecil dari 0,05 dapat diartikan bahwa kompensasi memiliki pengaruh secara parsial dan signifikan terhadap kepuasan kerja pada Dinas Pemberdayaan Masyarakat Gampong.

\section{KESIMPULAN DAN SARAN}

\subsection{Kesimpulan}

Dari hasil penelitian yang telah diuraikan di atas maka dapat di ambil kesimpulan sebagai berikut :

1. Dari hasil perhitungan pada Tabel 4.11 di atas, diperoleh $F_{\text {hitung 33,067 dengan tingkat }}$ probabilitas $0,00, \quad$ sedangkan $F_{\text {tabel }}$ sebesar 3,245. Karena probabilitas jauh lebih kecil dari 0,05. $F_{\text {hitung }}$ lebih besar dari $F_{\text {tabel }}$ maka dapat dikatakan bahwa variabel kepuasan kerja dipengaruhi secara simultan (bersama-sama) dan signifikan oleh budaya organisasi dan kompensasi pada Dinas Pemberdayaan Masyarakat Gampong Kabupaten Pidie.

2. Hasil penelitian terhadap pengaruh budaya organisasi 
diperoleh nilai $t_{\text {hitung }} 2,669$ sedangkan untuk nilai $\mathrm{t}_{\text {tabel }} 2,02$. Karena nilai $t_{\text {hitung }}$ lebih besar dari $t_{\text {tabel }}$ dengan tingkat signifikan sebesar 0.011 lebih kecil dari 0,05 dapat disimpulkan bahwa budaya organisasi memiliki pengaruh secara parsial dan signifikan terhadap kepuasan kerja pada Dinas Pemberdayaan Masyarakat Gampong.

3. Selanjutnya hasil penelitian terhadap pengaruh kompensasi diperoleh nilai $t_{\text {hitung }} 3,375$ sedangkan untuk nilai $t_{\text {tabel }} 2,02$. Karena nilai $t_{\text {hitung }}$ lebih besar dari $t_{\text {tabel }}$ dengan probabilitasnya sebesar 0.002 lebih kecil dari 0,05 dapat diartikan bahwa kompensasi memiliki pengaruh secara parsial dan signifikan terhadap kepuasan kerja pada Dinas Pemberdayaan Masyarakat Gampong.

\subsection{Saran}

Berdasarkan hasil penelitian yang telah dilakukan pada Dinas Pemberdayaan Masyarakat Gampong maka dapat disarankan beberapa hal sebagai berikut :

1. Berdasarkan hasil penelitian terhadap variabel budaya organisasi memiliki pengaruh terhadap kepuasan kerja pegawai, maka disarankan kepada pimpinan Dinas Pemberdayaan Masyarakat Gampong untuk memperhatikan budaya kerja organisasi di lingkungan Dinas Pemberdayaan Masyarakat Gampong Kabupaten Pidie agar dapat meningkatkan kepuasan kerja para pegawai.

2. Berdasarkan terhadap penelitian variabel kompensasi memiliki pengaruh terhadap kepuasan kerja pegawai, maka dari itu disarankan kepada pimpinan Dinas Pemberdayaan Masyarakat Gampong Kabupaten Pidie agar meningkatkan gaji pegawai seperti gaji lembur, bonus kinerja, bonus tahunan dan lainlain.

3. Disarankan kepada peniliti selanjutnya untuk menambahkan variabel lainnya seperti etos kerja, kompentensi, dan lain-lain agar hasil penelitian lebih akurat.

\section{DAFTAR PUSTAKA}

Arikunto, Suharsimi. 2010. Prosedur Penelitian (Suatu Pendekatan Praktek) Edisi Enam, Jakarta : Rineka Cipta.

Edison. 2016. Manajemen Sumber Daya Manusia. Bandung : Alfabeta.

Ghozali, Imam. 2016. Aplikasi Multivariate Dengan Program IBM SPSS 23. Semarang : Universitas Diponegoro.

Hasibuan, S. P Melayu. 2012. Manajemen Sumber Daya Manusia. Jakarta: Bumi Aksara.

Kadarisman, M. 2012. Manajemen Kompensasi, Jakarta: Rajawali Pers.

Kinicki, A. dan Kreitner, R. 2013. Organizational Behavior, 9th edition. New York: McGrawHill.

Lawler, Edward E \& Boudreau, J. W. (2015). Global Trends in Human Resource Management: A Twenty-Year 
Analysis. In Stanford Business Books

Luthan, Fred. 2011. Perilaku Organisasi, (Alih Bahasa V.A Yuwono, dkk, Edisi Bahasa Indonesia, Jakarta, PT. Indek

Mangkunegara, AA. Prabu. 2013. Manajemen Sumber Daya Manusia Perusahaan.

Bandung: Remaja Rosdakarya.

Mathis, R \& Jackson, W. 2006. Human Resources Development (Track MBA Series/terjemahan). Jakarta; Prestasi Pustaka.

Pengabean, Mutiara. (2012). "Manajemen Sumber Daya Manusia". Cetakan Keenam Belas, Penerbit Bumi Aksara, Jakarta.

Priansa, D. J. (2014). Perencanaan \& Pengembangan SDM. Alfabeta.

Rivai, Veithzal. (2011) Manajemen Sumber Daya manusia Untuk Perusahaan. Jakarta: PT. Rajagrafindo Persada.

Rivai, Veithzal., dan Sagala, Ella Jauvani 2010. Manajemen Sumber Daya Manusia untuk Perusahaan: dari Teori ke Praktik. Jakarta: Raja Grafindo Persada

Robbins, Stephen P dan Judge, Timothy A. (2015). Perilaku Organisasi, $\quad$ Edisi 16. Diterjemahkan oleh Ratna Saraswati daan Febriella Sirait. Jakarta : Salemba.
Robbins, Stephen $\mathrm{P}$ dan Timoty A.Judge. 2010. Perilaku Organisasi. Jakarta: Salemba

Robbins, Stephen P, 2009, Perilaku Organisasi, Jakarta : PT. Tema Baru

Sekaran. Uma. 2007. Metodologi Penelitian Untuk Bisnis, Edisi 4. Jakarta: Salemba Empat.

Sedarmayanti, 2010, Sumber Daya Manusia dan Produktivitas Kerja, Bandung : CV Mandar Maju

Sembiring, Masana. 2012. Budaya \& Kinerja Organisasi : Perspektif Organisasi Pemerintah. Bandung : Fokus Media.

Simamora, Henry. 2014. Manajemen Sumber Daya Manusia. Yogyakarta: STIE YKPN.

Sugiyono. 2010. Metode Penelitian Bisnis. Bandung : Alfabeta.

Sugiyono. 2017. Metode Penelitian Kuantitatif, Kualitatif, dan R\&D. CV.Alfabeta

Sudjana. 2012. Statistika Untuk Ekonomi dan Niaga. Bandung: Tarsito.

Suparno Eko. Widodo, 2015. Manajemen Pengembangan Sumber Daya Manusia. Yogyakarta: Pustaka Pelajar

Sutrisno, Edi. 2014. Manajemen Sumber Daya Manusia Edisi Pertama. Jakarta: Kencana Prenada Media Group. 
Jurnal Sains Riset (JSR)

$p$-ISSN 2088-0952, $e$-ISSN 2714-531X

DOI.

Umar, Husein. (2013). Desain

Penelitian MSDM dan

Perilaku Karyawan. Jakarta:

Rajawali Pers.

Yani (2012). Manajemen Sumber

Daya Manusia. Jakarta :Mitra

Wacana Media. 